University of Nebraska - Lincoln

DigitalCommons@University of Nebraska - Lincoln

2-17-1989

\title{
VARIANCE HETEROGENEITY IN DIRECT AND MATERNAL WEIGHT TRAITS BY SEX AND PERCENT PUREBRED FOR SIMMENTAL- SIRED CALVES
}

\author{
D. J. Garrick \\ Cornell University, D.Garrick@massey.ac.nz \\ E. J. Pollak \\ Cornell University, jpollak2@unl.edu \\ R. L. Quaas \\ Cornell University \\ L. Dale Van Vleck \\ University of Nebraska-Lincoln, dvan-vleck1@unl.edu
}

Follow this and additional works at: https://digitalcommons.unl.edu/animalscifacpub

Part of the Animal Sciences Commons

Garrick, D. J.; Pollak, E. J.; Quaas, R. L.; and Van Vleck, L. Dale, "VARIANCE HETEROGENEITY IN DIRECT AND MATERNAL WEIGHT TRAITS BY SEX AND PERCENT PUREBRED FOR SIMMENTAL-SIRED CALVES" (1989). Faculty Papers and Publications in Animal Science. 346.

https://digitalcommons.unl.edu/animalscifacpub/346

This Article is brought to you for free and open access by the Animal Science Department at DigitalCommons@University of Nebraska - Lincoln. It has been accepted for inclusion in Faculty Papers and Publications in Animal Science by an authorized administrator of DigitalCommons@University of Nebraska Lincoln. 


\title{
VARIANCE HETEROGENEITY IN DIRECT AND MATERNAL WEIGHT TRAITS BY SEX AND PERCENT PUREBRED FOR SIMMENTAL-SIRED CALVES1
}

\author{
D. J. Garrick, E. J. Pollak, R. L. Quaas and L. D. Van Vleck ${ }^{2}$ \\ Cornell University, Ithaca, NY 14853
}

\begin{abstract}
Phenotypic variances for linear and transformed weight traits were partitioned into residual, direct genetic (D) and maternal genetic $(M)$ components using REML techniques with American Simmental Association data from calves born 1969 to 1985. Variance components were estimated separately from subclasses defined by sex (male, female) and percent Simmental $(50, \geq 75)$. The model included fixed effects of contemporary group and age-of-dam $(<3,3$ to $5,>5 \mathrm{yr})$. Additive relationships among sires and maternal grandsires were included. Results follow for a sire-maternal grandsire model for $\geq 75 \%$ Simmental untransformed data based on 143,280 male and 281,805 female weaning weights (WW) representing 4,763 and 7,406 sires, respectively. Female results are bracketed. For computational simplification, 47,650 [30,909] postweaning gain (PW) records were included in the analysis only for $114,404[182,255]$ calves with birth weight (BW). Phenotypic standard deviations (kg) were: BW, 4.5 [4.1]; WW, 26.9 [23.2]; and PW, 25.9 [19.9]. Heritabilities were: BWD, .40 [.45]; WWD, .32 [.39]; PWD, .26 [.32]; BWM, .13 [.15]; WWM, .20 [.16]; and PWM, .01 [.01]. These heritabilities are higher than previously used for genetic evaluations in this breed. Moderate and positive correlations .26 to .50 , existed between direct effects and were similar for both sexes. Direct and maternal effects on the same trait were correlated negatively: BW, $-.45[-.31]$; and WW, $-.27[-.34]$. Genetic correlation between BWM and WWM was .53 [.49]. First-cross progeny exhibited less genetic and residual variation and had lower heritabilities than Simmental calves of higher percent. Correlations between sire evaluations on the subsets were consistent with those expected given a perfect genetic correlation between traits for each sex and percent Simmental. Logarithmic transformed records were no more homogeneous than untransformed records.

(Key Words: Beef Cattle, Maternal Effects, Transformation, Variance, Heterogeneity, Variance Components.)
\end{abstract}

J. Anim. Sci. 1989. 67:2515-2528

\section{Introduction}

Genetic evaluations for production traits often assume a linear model; the equation may include fixed effects (e.g., contemporary clas-

\footnotetext{
${ }^{1}$ Data and funding were provided by the Am. Simmental Assoc. This research was conducted using the Cornell National Supercomputing Facility, a resource of the Center for Theory and Simulation in Science and Engineering at Cornell University, which is funded in part by the National Science Foundation, New York State, and the IBM Corporation.

${ }^{2}$ Dept. of Anim. Sci.

Received September 14, 1988.

Accepted February 17, 1989.
}

sifications and age effects) and random effects (e.g., genetic and residual). Assuming random and residual effects follow a multivariate normal distribution, restricted maximum likelihood (REML) techniques can be used to estimate variances. To minimize the number of parameters to be estimated, it is tempting to assume homogeneous variance.

In beef cattle, phenotypic variance of weight increases with mean; for example, weaning weights have greater variance than birth weights. Typically, males are heavier and more variable than females of the same age. This implies that males and females do not have identical genetic and residual variance. 
TABLE 1. NUMBERS OF OBSERVATIONS AND MEANS (kg) BY CALF SEX FOR BIRTH WEIGHT (BW), WEANING WEIGHT (WW) AND YEARLING WEIGHT (YW)

\begin{tabular}{lrrr}
\hline & \multicolumn{3}{c}{ Sex of calf } \\
\cline { 2 - 4 } Traits & \multicolumn{1}{c}{ Bull } & Heifer & Steer \\
\hline BW $^{\mathbf{a}}$ & & & \\
No. & 220,269 & 369,933 & \\
Mean & 41 & 36 & \\
WW $^{\mathrm{b}}$ & & & \\
No. & 205,558 & 556,448 & 50,936 \\
Mean & 266 & 228 & 250 \\
YWc & & & \\
No. & 92,208 & 59,042 & 4,856 \\
Mean & 460 & 352 & 397 \\
\hline
\end{tabular}

adjusted for dam age.

bAdjusted to $205 \mathrm{~d}$.

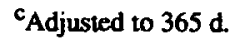

The objective of this study was to quantify heterogeneity for weight traits, by partitioning variation into direct and maternal genetic components, separately for males and females and for ïrst-cross calves compared to later generations of Simmental cattle. Furthermore, it was of interest to investigate power transformations of the observations that may result in homogeneous genetic and residual variance.

\section{Materials and Methods}

Description of Data. The American Simmental Association (ASA) made available data on calves born 1969 to 1985 that were used for the genetic evaluation published in the ASA 1987 Sire Selector. These data included birth weights (BW), weaning weights (WW) and yearling weights (YW) (Table 1). To be eligible for registration, a bull must have weaning and yearling weight records; a heifer is required to have a weaning weight record. Accordingly, all calves have weaning weight observations, whereas a lesser number have yearling weights recorded. A large proportion of calves have birth weight records, even though recording is not compulsory, which reflects breeder interest in this trait. Table 2 contains number of records characterized by trait combinations.

Prior to the genetic evaluation, these data had been edited for valid pedigree information and for weights outside ranges considered reasonable (BW, 23 to $64 \mathrm{~kg}$; WW, 91 to 682 kg; YW, 159 to $909 \mathrm{~kg}$ ). Observations had been assigned to contemporary groups, and
TABLE 2. DISTRIBUTION OF BIRTH WEIGHT (BW), WEANING WEIGHT (WW) AND YEARLING WEIGHT (YW) TRAIT COMBINATIONS

\begin{tabular}{lr}
\hline Trait combinations & No. of records \\
\hline WW only & 240,863 \\
BW, WW only & 377,082 \\
WW, YW only & 36,075 \\
BW, WW, YW & 158,053 \\
Total & 812,073 \\
\hline
\end{tabular}

only records from contemporary groups that were genetically connected with other contemporary groups through common sires were included. Furthermore, within a contemporary group, calves had to be weaned within the range of age (160 to $250 \mathrm{~d}$ ) defined by the Beef Improvement Federation (BIF). Singlesire contemporary groups had been removed. Further edits were carried out prior to estimating variance components. Records from any bull with more than two progeny or grandprogeny were included. Contemporary groups with no variation in birth weight within sex had BW observations excluded, because such records were assumed to be input standards. These data represented a total of 12,590 bulls appearing as sires, maternal grandsire or pedigree bulls (i.e., sires or maternal grandsires of other bulls, with no recorded progeny.)

Weight traits included in the Comell genetic evaluation for the ASA and the traits of interest are birth weight, weaning weight adjusted to $205 \mathrm{~d}$ (BIF, 1986) and postweaning gain adjusted to $160 \mathrm{~d}$. Adjusted 160-d postweaning gain (PW) is 365-d YW-205-d WW. The computation of variance components using REML was facilitated by transforming the data such that the transformed observations had an identity residual variance-covariance matrix. This required the following four assumptions and edits.

First, joint analysis of $50 \%$ and $\geq 75 \%$ Simmental calves required different residual variance-covariance matrices by percent Simmental because the residual variance for a calf with sire only known (50\% Simmental) includes the maternal grandsire variance. Firstcross $(50 \%)$ and $\geq 75 \%$ Simmental calves were analyzed separately with a sire and a sirematernal grandsire model, respectively.

Second, the model was assumed to include maternal effects for all three traits, BW, WW and PW. This contrasted with the model used for national evaluation of Simmental cattle, 
which does not include maternal effects for postweaning gain. There is some evidence for compensatory growth in this population (Elzo et al., 1987) such that Simmental females born out of younger dams have greater postweaning gain than do calves born to older dams. Young dams have lighter calves at weaning than do mature dams, which is due largely to less milk production. A maternal effect for postweaning gain would be expected if the dam effect for postweaning gain were negatively related to preweaning milk production. An objective of this analysis was to confirm the presence or absence of a postweaning maternal effect.

Third, practically all calves with weaning weight and yearling weight records had a birth weight observation (Table 2). Yearling weights from animals without birth weight were excluded to provide a sequential occurrence of trait combinations: WW only, WW and BW, or all three weights.

Fourth, contemporary groups were nested such that PW groups were contained within a single BW group, and the BW group was contained within a single WW group. In reality, from the chronological nature of these traits, a BW contemporary group may include several WW groups. This change in contemporary group nesting resulted in fitting more birth weight contemporary groups than would have been indicated from the actual contemporary groups present at calving. Including unnecessary fixed effects in the model increases the sampling variance of the estimators (Henderson, 1975) but may not be too serious a disadvantage in variance component estimation relative to its computational advantages.

Model for Weight Traits. The model for each weight trait comprised the following terms:

$$
\begin{aligned}
\mathrm{y}= & c g+(\text { sex, age-of-dam, \%Simmental }) \\
& +.5 \mathrm{u}_{\mathrm{D}(\mathrm{sire})}+.25 \mathrm{u}_{\mathrm{D}(\mathrm{mgs})} \\
& +.5 \mathrm{u}_{\mathrm{M}(\mathrm{mgs})}+\varepsilon
\end{aligned}
$$

where

$$
\begin{aligned}
& \mathrm{y}= \mathrm{BW}, 205-\mathrm{d} \mathrm{WW}, \text { or } 160-\mathrm{d} \\
& \mathrm{PW} ; \\
& \mathrm{cg}= \text { fixed contemporary group } \\
& \text { effect; }
\end{aligned}
$$

(sex, age-of- $=$ fixed effect associated with dam, \%Sim- sex-of-calf, age-of-dam mental) and percent Simmental combination;

$$
\begin{aligned}
u_{\mathrm{D}(\mathrm{sire}) \text { and }=} & \text { random direct genetic ef- } \\
\mathrm{u}_{\mathrm{D}(\mathrm{mgs})} & \text { fects of sire and maternal } \\
& \text { grandsire; } \\
\mathrm{u}_{\mathrm{M}(\mathrm{mgs})=} & \text { random maternal genetic } \\
& \text { effect (environmental ef- } \\
& \text { fect for the calf); and } \\
\varepsilon= & \text { random residual effect. } \\
& \text { This includes direct and } \\
& \text { maternal genetic contribu- } \\
& \text { tions of the maternal gran- } \\
& \text { ddam, and Mendelian sam- } \\
& \text { pling effects of the dam, } \\
& \text { direct effect Mendelian } \\
& \text { sampling of the calf and } \\
& \text { temporary and permanent } \\
& \text { environmental effects. }
\end{aligned}
$$

The sire-maternal grandsire model is equivalent to an animal model with direct and maternal effects provided that certain assumptions are satisfied. These include the following: 1) maternal granddams are unrelated and do not have more than one progeny; 2) maternal granddams were mated at random to maternal grandsires; 3) dams do not have more than one progeny; and 4) no information other than maternal grandsire merit was used to select mates for dams. There is some departure from these assumptions in the Simmental population (cows average less than two calvings); howev$\mathrm{er}$, the sire-maternal grandsire model is a reasonable approximation.

The contemporary groups were defined to group animals that received similar treatment. For animals to be included in the same contemporary group, the following criteria had to be met. All calves had to be identified by the same ASA breeder and herd codes and had to contain the same percent Simmental blood, either $50 \%, 75 \%$ or $\geq 87 \%$. These criteria removed the average effects of heterosis that otherwise would bias comparisons among animals of different percent Simmental blood. All contemporary calves were required to have been weighed on the same day. Finally, breeders had to assign identical pasture, management and feeding unit classifications to contemporary calves.

Sex effects for BW included classes for bulls and heifers. Analysis of WW and PW included three sex classes, bulls, heifers and steers. Although sex was not included in the contemporary group definition, $90 \%$ or more of contemporary groups contained calves of the same sex. For contemporary groups with mixed-sex calves in the analysis with sexes 
pooled, it was assumed that sex differences were constant in all groups.

Age-of-dam categories were $<3 \mathrm{yr}, 3$ to 5 $y r$, and $>5 \mathrm{yr}$, fewer categories than are used in the national evaluation. Sex by age-of-dam effects were fitted within percent Simmental for analyses that included both $75 \%$ and $\geq 87 \%$ Simmental calves. It was assumed that the non-Simmental composition of cross-bred calves did not make any difference to the sex $x$ age-of-dam interaction.

There are two equivalent models for (1) that result in quite different computational efforts to obtain estimates of $u_{D}\left(\right.$ sire), $u_{D}(m g s)$ and $u_{M}$ (mgs). In matrix notation, defining the vector $\beta$ to include fixed effects of contemporary group and sex by age-of-dam by percent Simmental interaction, using $X$ to denote the matrix associating effects in $\beta$ with $y, Z_{s}$ and $Z_{m}$ to denote the model matrices corresponding to sire and maternal grandsires, respectively, these two model equations are:

$$
y=X \beta+\left(Z_{s}+.5 Z_{m}\right) u_{D}+Z_{m} u_{M}+\varepsilon,
$$

and

$$
\mathbf{y}=\mathbf{x} \beta+\mathbf{z}_{\mathrm{s}} \mathbf{u}_{\mathrm{D}}+\mathbf{z}_{\mathrm{m}}\left(.5 \mathbf{u}_{\mathrm{D}}+\mathbf{u}_{\mathrm{M}}\right)+\varepsilon .
$$

The first expression, (2), involves a vector of direct and a vector of maternal effects. Corresponding to the direct effects are two incidence matrices, one for sires and one for maternal grandsires. The second expression, (3), involves a reparameterization to a sire effect and a matemal grandsire effect. The maternal grandsire effect is a function of direct and maternal effects. In some sense this is a natural parameterization, because an individual observation is affected by the maternal grandsire contribution of direct and maternal genes, which are completely confounded. Relative to Equation (3), fitting model (2) can result in considerable increase in number of nonzero elements in the coefficient matrix for the partition relating to direct effects. This fill increases the cost of forming and iterating mixed model equations. Accordingly, the multiple trait sire-maternal grandsire model equation in (3) was fitted to estimate variance components for $\geq 75 \%$ Simmental calves. Firstcross calves had unknown maternal grandsires and were analyzed for direct effects using a sire model. However, the estimates reported in this paper are causal components, corresponding to an animal equation rather than to sire and maternal grandsire components.

In comparing variance components estimated from $50 \%$ and $\geq 75 \%$ Simmental calves, it is difficult to interpret the differences as resulting from the nature of the data $(50 \%$ vs $\geq 75 \%$ ) or from the assumptions relating to the model (sire vs sire-maternal grandsire model). A greater estimated residual variance would be expected from a sire model relative to a sirematernal grandsire model due to the inadequacy of the sire model to account for assortative mating. Accordingly, the $\geq 75 \%$ data were subjected to analysis with a sire model as well as with a sire-maternal grandsire model.

Restricted Maximum Likelihood. Variance components were estimated using a generalized Expectation-Maximization algorithm (GEM) (Dempster et al., 1977) to obtain a constrained maximum of the restricted loglikelihood function. Computationally, the work required in a single iteration of a GEM algorithm is equivalent to evaluating the first derivative of the restricted log-likelihood function. In general, an evaluation of the first derivative requires obtaining BLUP solutions for random and residual effects and the prediction error variances of random and residual effects, conditional on a current estimate of variance components. Given an estimate of the residual variance-covariance matrix, a matrix can be found to premultiply the data vector such that the resultant vector can be described using a model with uncorrelated residuals. With uncorrelated residuals, the first derivative can sometimes be obtained as a function of the random effects and their prediction error variance, without obtaining solutions for residuals or residual prediction error variance.

Solutions to random effects were obtained after 100 rounds of block Gauss-Seidel iteration using blocks of order 6 defined by the sire and maternal grandsire coefficients corresponding to each bull. Prediction error variances of solutions to random effects were obtained from a second-order approximation based on a Taylor series expansion of a matrix inverse (Garrick, 1988). Iteration of variance components from $\geq 75 \%$ calves was begun using estimates from Elzo et al. (unpublished data) and continued for 90 iterations. There 
TABLE 3. NUMBERS OF OBSERVATIONS AND DEGREES OF FREEDOM

FOR BIRTH WEIGHT (BW), WEANING WEIGHT (WW) AND POSTWEANING GAIN (PW) BY SEX OF CALF WITHIN PERCENT SIMMENTAL.

\begin{tabular}{|c|c|c|c|c|}
\hline \multirow[b]{2}{*}{ Traits } & \multicolumn{2}{|c|}{$50 \%$ Simmental } & \multicolumn{2}{|c|}{$\geq 75 \%$ Simmental } \\
\hline & $\begin{array}{l}\text { Female } \\
\text { calf }\end{array}$ & $\begin{array}{l}\text { Male } \\
\text { calf }\end{array}$ & $\begin{array}{l}\text { Female } \\
\text { calf }\end{array}$ & $\begin{array}{l}\text { Male } \\
\text { calf }\end{array}$ \\
\hline & 2,554 & 1,471 & 7,406 & 4,763 \\
\hline $\begin{array}{l}\text { WW } \\
\text { BW } \\
\text { PW }\end{array}$ & $\begin{array}{r}192,272 \\
91,438 \\
12,823\end{array}$ & $\begin{array}{l}51,781 \\
37,674 \\
12,106\end{array}$ & $\begin{array}{r}281,805 \\
182,255 \\
30,909\end{array}$ & $\begin{array}{r}143,280 \\
114,404 \\
47,650\end{array}$ \\
\hline $\begin{array}{l}\text { WW } \\
\text { BW } \\
\text { PW }\end{array}$ & $\begin{array}{r}173,506 \\
82,199 \\
11,652\end{array}$ & $\begin{array}{l}46,761 \\
34,137 \\
10,795\end{array}$ & $\begin{array}{r}243,361 \\
158,188 \\
27,484\end{array}$ & $\begin{array}{r}122,735 \\
98,608 \\
38,750\end{array}$ \\
\hline
\end{tabular}

was no practical or appreciable change in estimates over the last 30 iterations. Subsets of the data were iterated 45 rounds from the converged solution for $\geq 75 \%$ calves. Starting values for estimates of phenotypic variance of log-transformed data were obtained by dividing the phenotypic variance for the untransformed data by the square of the mean. Variance and covariance estimates then were derived using heritabilities and correlations obtained from the analysis of the untransformed data.

Additive genetic relationships among sires and maternal grandsires were included in the analysis by transforming the mixed model equations. Algebraically, the transformation involved premultiplying the left- and righthand sides of the mixed model equations with a modifying matrix and inserting the modifying matrix and its inverse between the coefficient matrix and the solution vector. The partition of the modifying matrix corresponding to random effects is a Kronecker product involving a Cholesky decomposition of the additive relationship matrix and an identity matrix. In practice, the transformation can be achieved by sequential permutation of the least squares contribution to the mixed model coefficient matrix (Quaas, 1989).

The sampling variance-covariance matrix for estimated variance components was obtained from the inverse of the negative of the estimated matrix of second derivatives. The second derivative matrix was approximated using the method of finite difference (Dennis and Schnabel, 1983).
Definition of Data Subclasses. Distribution of observations and degrees of freedom among the three traits are summarized in Table 3 for data sets partitioned according to calf sex (male, female) within percent Simmental (50, 275 ). Degrees of freedom are the number of observations adjusted for the number of contemporary groups and sex by age-of-dam by percent Simmental effects. A prominent feature of these data was the large proportion of missing observations. Although the majority of the records comprise observations on heifer calves, a higher proportion of postweaning gain records was present for males. Male records can be reported selectively because the ASA registration requirements allow an entire calf record to be submitted by breeders after yearlings have been weighed.

Analysis of records from mixed sexes within percent Simmental subclasses contained $2,922(50 \%)$ and $8,369(\geq 75 \%)$ sires. Numbers of observations and degrees of freedom can be closely approximated by summing the information in Table 3 within percent Simmental subclass. These sums are approximations because the within-sex subclass data were reedited for single sire contemporary groups and for sires with $\leq 2$ progeny and $\leq 2$ grandprogeny.

Genetic Correlations between Subclasses. National genetic evaluations for beef cattle in North America assume identical expression of additive genes regardless of calf sex. The evaluation of the American Simmental breed further assumes that the relative performance of first-cross contemporaries is determined by 
the same genes that determine relative performance of contemporary cattle from later generations. That is, a unit genetic correlation is assumed to relate performance in each sexpercent Simmental subclass. To investigate this assumption, one would ideally estimate variance components from a multiple-trait system using weights in each sex-percent subclass as different traits. That is computationally difficult because the system of equations to solve for random effects becomes very large and the genetic variance-covariance matrix will approach singularity as the genetic correlation between subclasses approaches one.

An approximate method for validating the assumption of unit genetic correlation between subclasses involves comparing observed and expected correlations of estimated predicted differences obtained in independent data sets. Observed correlations are product-moment correlations between separate evaluations of sires with progeny represented in two subclasses. The expected correlation can be obtained using selection index theory to derive the expression:

$$
r_{\hat{g}_{1} \hat{g}_{2}}=r_{g_{1} g_{2}} \cdot r_{g_{1} \hat{g}_{1}} \cdot r_{g_{2} \hat{g}_{2}}
$$

where subscripts 1 and 2 define subclasses, $g_{i}$ and $\hat{\mathbf{g}}_{i}$ are actual and predicted merit in subclass i. Assuming a unit genetic correlation between subclasses, $r_{g_{1}} g_{2}=1$, then the expected correlation between evaluations is:

$$
r_{\hat{g}_{1} \hat{g}_{2}}=r_{g_{1} \hat{g}_{1}} \cdot r_{g_{2} \hat{g}_{2}}
$$

the product of correlations between true and index value in each environment. These terms on the right-hand side of (5) can be obtained from prediction error variances, which are elements of the inverse of the mixed model coefficient matrix.

Investigation of Transformations. Power transformations $\left(y^{p}\right.$ for $p \in[-2,2]$ or $\log (y)$ for $p=0$ ) were considered for transforming weight traits to remove variance heterogeneity. Initial investigations involved fitting a single trait fixed effects model to transformed observations for varying $p$. The model included effects for contemporary groups, sex by ageof-dam by percent Simmental subclasses [INTERCEPT] and date of birth (BW), age at weaning (WW) or gain days (PW) as a covariate [SLOPE]. The absolute values of residuals obtained from the fixed effects model then were analyzed using a model equation containing INTERCEPT and SLOPE effects. If the power transformation removed heterogeneity, one would expect the average magnitude of a residual to be identical regardless of INTERCEPT or SLOPE. Accordingly, for varying $\mathrm{p}$, minimum ratios of mean squares for INTERCEPT and SLOPE relative to error mean square (Table 4) were used to identify a useful transformation. On this basis, logtransformations were considered to be worthy of further investigation using mixed model techniques. Variance components were esti-

TABLE 4. RATIOS OF MEAN SQUARES FOR FIXED EFFECTS ANAL YSIS OF ABSOLUTE VALUE RESIDUALS OVER A

\begin{tabular}{|c|c|c|c|c|c|c|c|c|c|c|}
\hline \multirow{2}{*}{$\begin{array}{l}\text { Model } \\
\text { df }\end{array}$} & \multirow[b]{2}{*}{ Source } & \multicolumn{9}{|c|}{ Transformation } \\
\hline & & -2.0 & -1.5 & -1.0 & -.5 & $\log$ & .5 & 1.0 & 1.5 & 2.0 \\
\hline $\begin{array}{l}72 \\
69\end{array}$ & $\begin{array}{l}\text { Slope } \\
\text { Intercept }\end{array}$ & $\begin{array}{r}49.3 \\
1.2\end{array}$ & $\begin{array}{r}34.8 \\
1.1\end{array}$ & $\begin{array}{r}22.6 \\
1.0\end{array}$ & $\begin{array}{r}13.7 \\
1.0\end{array}$ & $\begin{array}{l}9.2 \\
1.1\end{array}$ & $\begin{array}{l}9.6 \\
1.3\end{array}$ & $\begin{array}{r}15.1 \\
1.6\end{array}$ & $\begin{array}{r}25.4 \\
2.0\end{array}$ & $\begin{array}{r}39.8 \\
2.5\end{array}$ \\
\hline $\begin{array}{l}109 \\
105\end{array}$ & $\begin{array}{l}\text { Slope } \\
\text { Intercept }\end{array}$ & $\begin{array}{r}36.1 \\
4.3\end{array}$ & $\begin{array}{r}34.4 \\
4.2\end{array}$ & $\begin{array}{r}29.5 \\
3.9\end{array}$ & $\begin{array}{r}23.3 \\
3.5\end{array}$ & $\begin{array}{r}18.7 \\
2.9\end{array}$ & $\begin{array}{r}18.2 \\
2.4\end{array}$ & $\begin{array}{r}23.6 \\
2.2\end{array}$ & $\begin{array}{r}35.4 \\
2.3\end{array}$ & $\begin{array}{r}53.1 \\
2.8\end{array}$ \\
\hline $\begin{array}{l}109 \\
105\end{array}$ & $\begin{array}{l}\text { Slope } \\
\text { Intercept }\end{array}$ & $\begin{array}{r}41.6 \\
4.4\end{array}$ & $\begin{array}{r}34.8 \\
4.1\end{array}$ & $\begin{array}{r}27.0 \\
3.7\end{array}$ & $\begin{array}{r}19.9 \\
3.2\end{array}$ & $\begin{array}{r}15.5 \\
2.7\end{array}$ & $\begin{array}{r}15.3 \\
2.3\end{array}$ & $\begin{array}{r}20.5 \\
2.1\end{array}$ & $\begin{array}{r}31.3 \\
2.2\end{array}$ & $\begin{array}{r}47.4 \\
2.6\end{array}$ \\
\hline $\begin{array}{l}108 \\
103\end{array}$ & $\begin{array}{l}\text { Slope } \\
\text { Intercept }\end{array}$ & $\begin{array}{r}3.4 \\
.7\end{array}$ & $\begin{array}{r}3.2 \\
.7\end{array}$ & $\begin{array}{r}2.7 \\
.7\end{array}$ & $\begin{array}{l}2.1 \\
1.4\end{array}$ & $\begin{array}{l}1.9 \\
1.8\end{array}$ & $\begin{array}{l}3.1 \\
2.1\end{array}$ & $\begin{array}{l}1.6 \\
7.9\end{array}$ & $\begin{array}{r}2.0 \\
10.7\end{array}$ & $\begin{array}{r}3.0 \\
10.2\end{array}$ \\
\hline
\end{tabular}
RANGE OF POWER TRANSFORMATIONS 
TABLE 5. ESTIMATED DIRECT (D) AND MATERNAL (M) (CO)VARIANCE

COMPONENTS $\left(\mathrm{kg}^{2}\right)$ AND STANDARD ERRORS (kg) FOR

BIRTH WEIGHT (BW), WEANING WEIGHT (WW) AND POSTWEANING GAIN (PW) OF $\geq 75 \%$ SIMMENTAL CALVES

\begin{tabular}{llllllll}
\hline \hline & \multicolumn{7}{c}{ Genetic components } \\
\cline { 2 - 7 } Traits & BWD & WWD & PWD & BWM & WWM & PWM \\
\hline BWD & $7.9(.7)$ & & & & & & \\
WWD & $4.1(.7)$ & 223 & $(21)$ & & & & \\
PWD & 11 & $(4)$ & 94 & $(21)$ & $151(29)$ & & \\
BWM & $-1.6(.5)$ & $-.3(2.6)$ & $1(3)$ & $2.2(.4)$ & & \\
WWM & $-4.5(3)$ & -52 & $(17)$ & $-3(19)$ & $7(2.5)$ & $120(21)$ & \\
PWM & $-1.8(2.5)$ & -18 & $(16)$ & $-8(12)$ & $.8(1.4)$ & $16(13)$ & $6(6)$ \\
\hline
\end{tabular}

mated using REML (assuming multivariate normality) for log-transformed $B W, W W$ and PW, using the same model and computational techniques that had been applied to untransformed weights. Effects in both log-transformed and untransformed models cannot follow a multivariate normal distribution; however, there is little statistical methodology available to enable discrimination among possible distributions underlying realizations of random effects in mixed models. In reality, observations may result from processes that include multiplicative and additive effects. In such a case, there is unlikely to be any transformation that removed heterogeneity of genetic and residual effects or a transformation that results in effects that are normally distributed. It is even less likely that such transformations would coincide.

\section{Results and Discussion}

\section{Analysis by Percent Simmental with Sexes Pooled}

Estimated genetic and residual variancecovariance components are given in Tables 5 and 6 with their (approximate) asymptotic standard errors. Standard errors were small relative to the magnitude of the direct variance estimates for BW and WW. Standard error was relatively larger for the estimate of $P W$ direct effects, probably as a result of missing observations for PW. Compared to relative errors for direct effects, relative errors for maternal variance estimates were larger, which reflects confounding of maternal grandsire contributions of direct and maternal genes. Maternal genetic variance for PW was small relative to its standard error. Table 7 presents estimated genetic and residual variance components and genetic, residual and phenotypic correlations.

Heritabilities. Heritabilities of BW and WW direct effects were considerably higher than the starting values (Table 7). Relative to starting values, the increased heritabilities resulted from repartitioning residual variance into additive genetic variance. Heritabilities were greater in $275 \%$ Simmental calves relative to first-cross calves. Estimates for $\geq 75 \%$ calves from a sire-maternal grandsire model were greater than estimates from a sire model. Heritabilities of maternal effects, defined as the ratio of maternal genetic variance to phenotypic variance, were higher than starting values for BW and WW. Heritability for PW maternal effects was close to zero, confirming that maternal effects for this trait need not be included in genetic evaluations. Strictly speaking, maternal heritability would be defined as the ratio of maternal genetic variance to total maternal variance. However, the model fitted in this analysis did not enable estimation of permanent or temporary maternal environmental variance.

Correlations. Phenotypic correlations (Table 7) were similar to assumed starting values

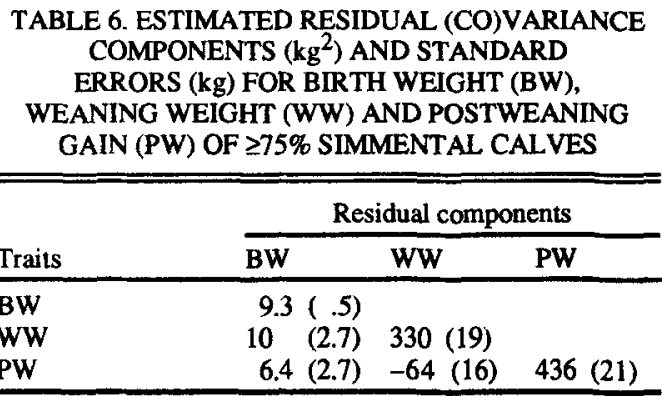


and did not differ by percent Simmental. Genetic correlations among direct effects were similar to starting values for all subclasses, that is, moderately high and positive. Correlations between direct and maternal effects for the same trait were negative, -.38 for $\mathrm{BW}$ and -.32 for WW. Negative correlations were expected between direct and maternal effects as a consequence of natural selection for an intermediate optima. The negative correlation was indicative of an incompatibility between genes that enhance an animal's own growth and genes that result in superior maternal performance of a heifer. Correlations between

TABLE 7. VARIANCE COMPONENTS $\left(\mathrm{kg}^{2}\right)$, HERITABILITIES AND CORRELATIONS FOR DIRECT (D) AND MATERNAL (M) GENETIC EFFECTS ON BIRTH WEIGHT (BW), WEANING WEIGHT (WW) AND POSTWEANING GAIN (PW) BY PERCENT SIMMENTAL.

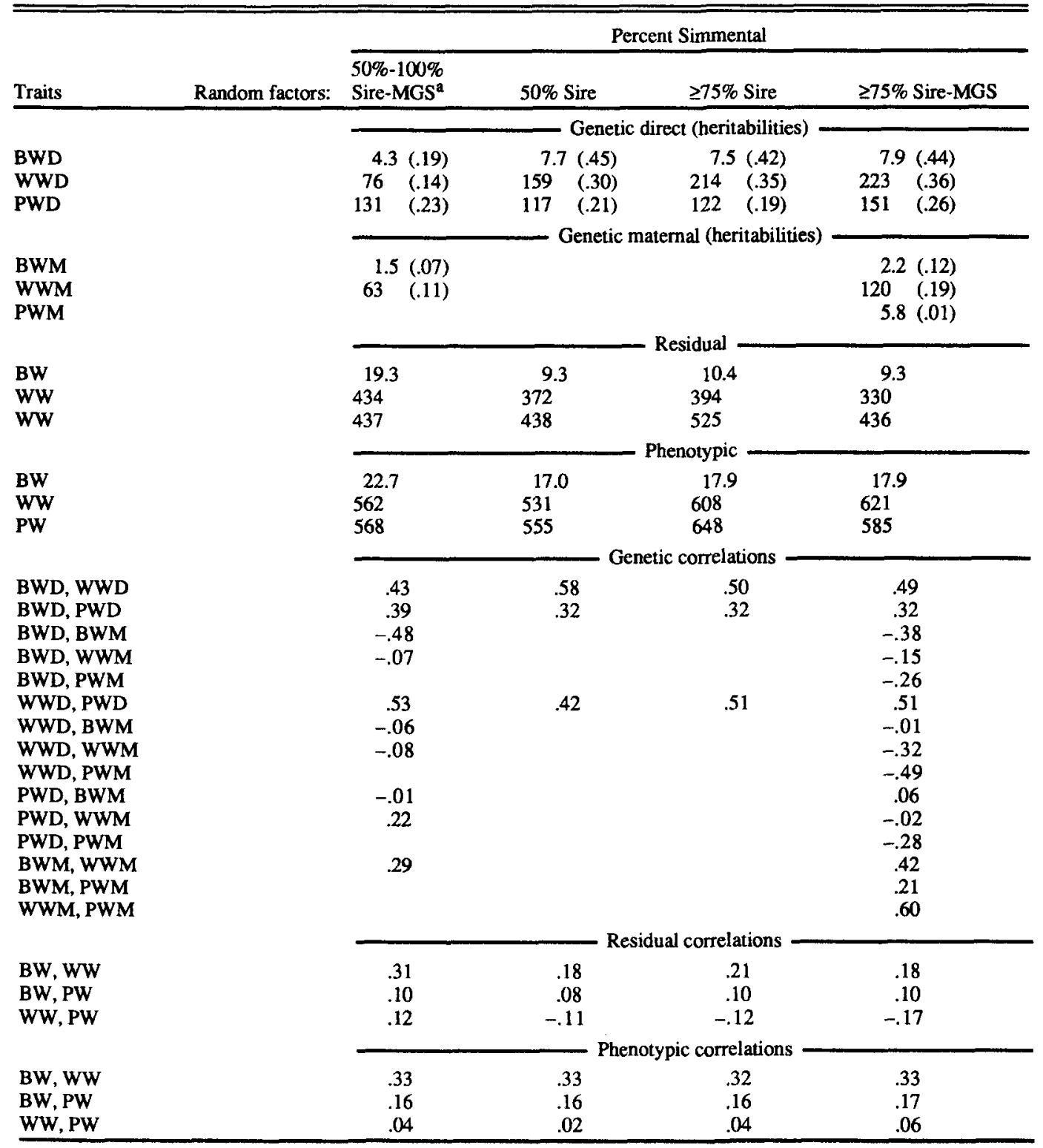

astarting values from Elzo et al. (unpublished data). MGS = maternal grandsire. 
TABLE 8. VARIANCE COMPONENTS $\left(\mathrm{kg}^{2}\right)$ AND CORRELATIONS FOR DIRECT (D) AND MATERNAL (M) GENETIC EFFECTS ON BIRTH WT (BW) WEANING WEIGHT (WW) AND POSTWEANING GAIN (PW), WITHIN SEX BY PERCENT SIMMENTAL

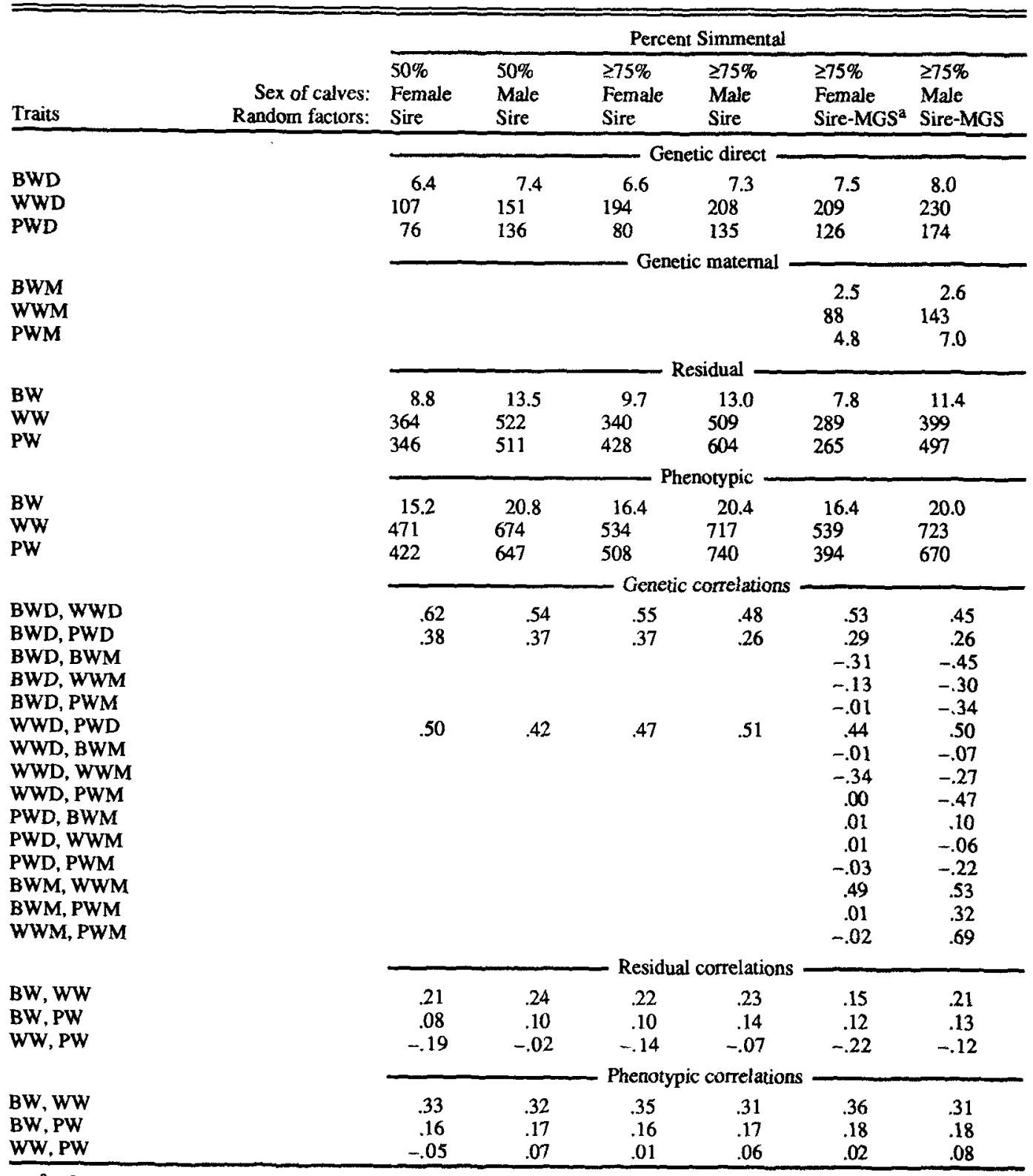

${ }^{\mathrm{a}} \mathrm{MGS}=$ maternal grandsire.

maternal effects for different traits were positive. Correlations involving PW maternal effects probably are not meaningful because the covariance estimate was, in most cases, smaller than its estimated standard error (Table 5). Residual correlation between WW and PW was small and negative. A negative residual correlation was expected because WW is the pivotal weight used in calculating PW. Any error that results in overestimating actual WW results in underestimating $\mathrm{PW}$.

\section{Analysis Within Sex by Percent Simmental Subclass}

Variance components and correlations are given in Table 8 for sex by percent Simmental 
TABLE 9. DIRECT (D) AND MATERNAL (M) HERITABILITIES FOR BIRTH WEIGHT (BW), WEANING WEIGHT (WW) AND POSTWEANING GAIN (PW) BY SEX AND PERCENT SIMMENTAL

\begin{tabular}{|c|c|c|c|c|c|c|c|c|c|c|}
\hline \multirow[b]{2}{*}{ Traits } & \multirow[b]{2}{*}{$\begin{array}{r}\text { Random factors: } \\
\text { Calf sex: }\end{array}$} & \multicolumn{9}{|c|}{ Percent Simmental } \\
\hline & & Female & $\begin{array}{l}50 \% \\
\text { Sire } \\
\text { All }\end{array}$ & Male & Female & $\begin{array}{l}\geq 750 \\
\text { Sire } \\
\text { All }\end{array}$ & Male & Female & $\begin{array}{l}\geq 75 \% \\
\text { Sire/MGS } \\
\text { All }\end{array}$ & Male \\
\hline & & & & & & Heri & silities & & & \\
\hline $\begin{array}{l}\text { BWD } \\
\text { WWD } \\
\text { PWD } \\
\text { BWM } \\
\text { WWM } \\
\text { PWM }\end{array}$ & & $\begin{array}{l}.42 \\
.23 \\
.18\end{array}$ & $\begin{array}{l}.45 \\
.30 \\
.21\end{array}$ & $\begin{array}{l}.35 \\
.22 \\
.21\end{array}$ & $\begin{array}{l}.40 \\
.36 \\
.16\end{array}$ & $\begin{array}{l}.42 \\
.35 \\
.19\end{array}$ & $\begin{array}{l}.36 \\
.29 \\
.18\end{array}$ & $\begin{array}{l}.45 \\
.39 \\
.32 \\
.15 \\
.16 \\
.01\end{array}$ & $\begin{array}{l}.44 \\
.36 \\
.26 \\
.12 \\
.19 \\
.01\end{array}$ & $\begin{array}{l}.40 \\
.32 \\
.26 \\
.13 \\
.20 \\
.01\end{array}$ \\
\hline
\end{tabular}

${ }^{2}$ MGS = maternal grandsire.

subclasses. Corresponding heritabilities are given in Table 9. There appears to be consistency among estimates of correlations obtained within the subclasses, with the exception of correlations involving PW maternal effects, which are likely to have large estimation errors. There was a consistent increase in phenotypic variance for males relative to females. This increase resulted from greater direct and maternal genetic variance in addition to greater residual variance. However, proportionally, the residual variance showed greater increase in males relative to females than did the genetic variance. This generally resulted in a decrease in heritabilities of direct effects for males compared to females. There was little difference in the maternal heritability for males and females. Estimates from analyses with sexes pooled were, in general, midway between the separate male and females estimates.

\section{Correlations Between Independent Subclasses}

Observed and expected correlations were calculated for bulls that had been separately evaluated in two of the subclasses. Correlations were obtained separately for bulls that were accurately evaluated (correlation of true and predicted merit, $\mathrm{r}_{\mathrm{g}_{\mathrm{i}} \hat{\mathrm{g}}_{\mathrm{i}}} \geq .9$ in both subclasses and for all bulls $\left(\mathrm{r}_{\mathrm{g}_{\mathrm{i}} \hat{\mathrm{g}}_{\mathrm{i}}} \geq 1\right.$ ). The results are given in Table 10 for correlations between independent evaluations using $\geq 75 \%$ male and $\geq 75 \%$-female records. Correlations for direct effects between $50 \%$-male and $\geq 75 \%$-male subclasses are given in Table 11 and between $50 \%$-female and $\geq 75 \%$-female subclasses are given in Table 12. The observed and expected correlations for bulls with $\mathbf{r}_{\mathrm{g}_{\mathrm{i}} \hat{\mathrm{g}}_{\mathrm{i}}} \geq$ .1 are consistently of similar magnitude with the exception of effects involving postweaning

TABLE 10. CORRELATIONS BETWEEN MALE AND FEMALE EFFECTS FOR DIRECT (D) AND MATERNAL (M) FACTORS FOR BIRTH WEIGHT (BW), WEANING WEIGHT (WW) AND POSTWEANING GAIN (PW)

\begin{tabular}{|c|c|c|c|c|c|c|}
\hline \multirow[b]{3}{*}{ Traits } & \multirow[b]{3}{*}{ No. of bulls } & \multicolumn{5}{|c|}{ Accuracy ${ }^{\mathrm{a}}$ of expected progeny differences } \\
\hline & & \multicolumn{2}{|c|}{$\geq .1$ Correlations $^{b}$} & & \multicolumn{2}{|c|}{$\geq .9$ Correlations } \\
\hline & & Observed & Expected & No. of bulls & Observed & Expected \\
\hline BWD & 1,267 & .61 & .57 & 201 & .83 & .92 \\
\hline WWD & 1,216 & .50 & .54 & 171 & .81 & .93 \\
\hline PWD & 1,267 & .54 & .39 & 85 & .76 & .91 \\
\hline BWM & 1,267 & .53 & .54 & 123 & .86 & .93 \\
\hline WWM & 1,246 & .47 & .45 & 156 & .81 & .93 \\
\hline PWM & 1,267 & .52 & .39 & 79 & .72 & .91 \\
\hline
\end{tabular}

${ }^{a}$ Correlation between actual and estimated predicted difference, $\operatorname{corr}\left(\mathrm{g}_{1}, \hat{\mathrm{g}}_{1}\right)$ and $\operatorname{corr}\left(\mathrm{g}_{2}, \hat{\mathrm{g}}_{2}\right)$.

${ }^{\mathrm{b}}$ Correlation of expected progeny difference, $\operatorname{corr}\left(\hat{\mathrm{g}}_{1}, \hat{\mathrm{g}}_{2}\right)$. 
TABLE 11. CORRELATIONS BETWEEN 50\% AND $\geq 75 \%$ SIMMENTAL EFFECTS FOR DIRECT (D) FACTORS FOR BIRTH WEIGHT (BW), WEANING WEIGHT (WW) AND POSTWEANING GAIN (PW) IN MALE CALVES

\begin{tabular}{|c|c|c|c|c|c|c|}
\hline \multirow[b]{3}{*}{ Traits } & \multirow[b]{3}{*}{ No. of bulls } & \multicolumn{5}{|c|}{ Accuracy ${ }^{2}$ of expected progeny differences } \\
\hline & & \multicolumn{2}{|c|}{$\geq .1$ Correlations $^{\mathrm{b}}$} & & \multicolumn{2}{|c|}{$\geq .9$ Correlations } \\
\hline & & Observed & Expected & No. of bulls & Observed & Expected \\
\hline BWD & 297 & .59 & .61 & 71 & .69 & .92 \\
\hline WWD & 279 & .50 & .55 & 58 & .61 & .92 \\
\hline PWD & 297 & .52 & .42 & 18 & .71 & .93 \\
\hline
\end{tabular}

${ }^{2}$ Correlation between actual and estimated predicted difference, $\operatorname{corr}\left(\mathrm{g}_{1}, \hat{\mathrm{g}}_{1}\right)$ and $\operatorname{corr}\left(\mathrm{g}_{2}, \hat{\mathrm{g}}_{2}\right)$.

bCorrelation of expected progeny difference, $\operatorname{corr}\left(\hat{\mathrm{g}}_{1}, \hat{\mathrm{g}}_{2}\right)$.

gain, which have a tendency to be more highly correlated than expected. A possible explanation for observed correlations being greater than expected is that the heritability for postweaning gain used in these evaluations was an underestimate of the true heritability. The observed correlations of expected progeny differences from bulls with $r_{g_{i} \hat{g}_{i}} \geq .9$ were consistently less than the expected correlations. This could result from nonrandom sampling of bulls with high accuracy of evaluation in the subclasses.

A multiple-trait analysis involving postweaning gain by sex as separate traits is worthy of further investigation. However, in the meantime, these results support the assumption that a large fraction of additive genes for weight traits have the same effect with regard to controlling variation in each of the sex-percent Simmental subclasses. That is, the genetic correlation between a random factor in each sex-percent subclass likely is close to unity.

\section{Analysis of Log-Transformed Data}

Variance components for sex by percent Simmental subclass are given in Table 13 for analysis of log-transformed weights. Heritabilities from the log analyses are given in Table 14. It is readily apparent that the transformed observations do not have homogeneous variance, although $\mathrm{BW}$ and WW transformations may have reduced the level of homogeneity. Transformation for PW increased heterogeneity, such that females had greater phenotypic variance on the transformed scale. This likely is a reflection that the variance of males relative to females did not increase with the mean as rapidly for $\mathrm{PW}$ as for $\mathrm{BW}$ and $\mathrm{WW}$, because the phenotypic standard deviation for log-transformed records was approximately the ratio of the standard deviation to the mean.

\section{Summary and Conclusions}

Estimated variance components for weight traits have moderate to high heritabilities,

TABLE 12. CORRELATIONS BETWEEN 50\% AND $\geq 75 \%$ SIMMENTAL EFFECTS FOR DIRECT (D) FACTORS FOR BIRTH WEIGHT (BW), WEANING WEIGHT (WW) AND POSTWEANING GAIN (PW) IN FEMALE CALVES

\begin{tabular}{lllllll}
\hline & & \multicolumn{4}{c}{ Accuracy $^{\mathrm{a}}$ of expected progeny differences } \\
\cline { 3 - 7 } & & \multicolumn{2}{c}{$\geq .1$ Correlations $^{\mathrm{b}}$} & \multicolumn{2}{c}{$\geq .9$ Correlations } \\
\cline { 3 - 7 } Traits & No. of bulls & Observed & Expected & No. of bulls & Observed & Expected \\
\hline BWD & 501 & .56 & .63 & 122 & .84 & .94 \\
WWD & 484 & .47 & .59 & 118 & .80 & .94 \\
PWD & 501 & .54 & .36 & 23 & .86 & .93 \\
\hline
\end{tabular}

${ }^{a}$ Correlation between actual and estimated predicted difference, $\operatorname{corr}\left(\mathrm{g}_{1}, \hat{\mathrm{g}}_{1}\right)$ and $\operatorname{corr}\left(\mathrm{g}_{2}, \hat{\mathrm{g}}_{2}\right)$.

${ }^{b}$ Correlation of expected progeny difference, $\operatorname{corr}\left(\hat{\mathrm{g}}_{1}, \hat{\mathrm{g}}_{2}\right)$. 
TABLE 13. VARIANCE COMPONENTS AND CORRELATIONS FOR DIRECT (D) AND MATERNAL (M) EFFECTS OF LOG-TRANSFORMED BIRTH WEIGHT (BW), WEANING WEIGHT (WW) AND POSTWEANING GAIN (PW) BY SEX AND PERCENT SIMMENTAL

\begin{tabular}{|c|c|c|c|c|c|c|c|}
\hline \multirow[b]{2}{*}{ Traits } & \multirow[b]{2}{*}{$\begin{array}{r}\text { Sex of calves: } \\
\text { Random factors: }\end{array}$} & \multicolumn{6}{|c|}{ Percent Simmental } \\
\hline & & $\begin{array}{l}50 \% \\
\text { Female } \\
\text { Sire }\end{array}$ & $\begin{array}{l}50 \% \\
\text { All } \\
\text { Sire } \\
\end{array}$ & $\begin{array}{l}50 \% \\
\text { Male } \\
\text { Sire }\end{array}$ & $\begin{array}{l}\geq 75 \% \\
\text { Female } \\
\text { Sire-MGS }\end{array}$ & $\begin{array}{l}\geq 75 \% \\
\text { All } \\
\text { Sire-MGS }\end{array}$ & $\begin{array}{l}\geq 75 \% \\
\text { Male } \\
\text { Sire-MGS }\end{array}$ \\
\hline $\begin{array}{l}\text { BWD } \\
\text { WWD } \\
\text { PWD }\end{array}$ & & $\begin{array}{l}.45 \\
.20 \\
.70\end{array}$ & $\begin{array}{l}.50 \\
.26 \\
.72\end{array}$ & $\begin{array}{l}.43 \\
.26 \\
.40\end{array}$ & $\begin{array}{l}.49 \\
.36 \\
.88\end{array}$ & $\begin{array}{l}.52 \\
.38 \\
.68\end{array}$ & $\begin{array}{l}.48 \\
.36 \\
.60\end{array}$ \\
\hline $\begin{array}{l}\text { BWM } \\
\text { WWM } \\
\text { PWM }\end{array}$ & & & & & $\begin{array}{l}.11 \\
.14 \\
.02\end{array}$ & $\begin{array}{l}.14 \\
.20 \\
.02\end{array}$ & $\begin{array}{l}.16 \\
.23 \\
.02\end{array}$ \\
\hline $\begin{array}{l}\text { BW } \\
\text { WW } \\
\text { PW }\end{array}$ & & $\begin{array}{r}.70 \\
.93 \\
5.59\end{array}$ & $\begin{array}{r}.71 \\
.93 \\
4.05\end{array}$ & $\begin{array}{r}.89 \\
1.08 \\
2.76\end{array}$ & $\begin{array}{r}.62 \\
.62 \\
4.01\end{array}$ & $\begin{array}{r}.62 \\
.63 \\
3.12\end{array}$ & $\begin{array}{r}.69 \\
.69 \\
2.03\end{array}$ \\
\hline $\begin{array}{l}\text { BW } \\
\text { WW } \\
\text { PW }\end{array}$ & & $\begin{array}{l}1.15 \\
1.13 \\
6.28\end{array}$ & $\begin{array}{l}1.21 \\
1.19 \\
4.77\end{array}$ & $\begin{array}{l}1.32 \\
1.34 \\
3.16\end{array}$ & $\begin{array}{l}1.13 \\
1.04 \\
4.83\end{array}$ & $\begin{array}{l}1.18 \\
1.13 \\
3.75\end{array}$ & $\begin{array}{l}1.21 \\
1.21 \\
2.58\end{array}$ \\
\hline $\begin{array}{l}\text { BWD, WWD } \\
\text { BWD, PWD } \\
\text { BWD, BWM } \\
\text { BWD, WWM } \\
\text { BWD, PWM } \\
\text { WWD, PWD } \\
\text { WWD, BWM } \\
\text { WWD, WWM } \\
\text { WWD, PWM } \\
\text { PWD, BWM } \\
\text { PWD, WWM } \\
\text { PWD, PWM } \\
\text { BWM, WWM } \\
\text { BWM, PWM } \\
\text { WWM, PWM }\end{array}$ & & $\begin{array}{l}.61 \\
.38\end{array}$ & $\begin{array}{l}.57 \\
.31\end{array}$ & $\begin{array}{l}.51 \\
.39\end{array}$ & $\begin{array}{r}.55 \\
.34 \\
-.39 \\
-.18 \\
-.58 \\
.42 \\
-.02 \\
-.34 \\
-.29 \\
.09 \\
.07 \\
-.61 \\
.43 \\
.20 \\
.09\end{array}$ & $\begin{array}{r}.49 \\
.30 \\
-.39 \\
-.15 \\
-.40 \\
.44 \\
-.02 \\
-.32 \\
-.29 \\
.10 \\
.04 \\
-.56 \\
.43 \\
.17 \\
.30\end{array}$ & $\begin{array}{r}.44 \\
.26 \\
-.44 \\
-.28 \\
-.38 \\
.47 \\
-.03 \\
-.25 \\
-.27 \\
.12 \\
-.04 \\
-.58 \\
.52 \\
.21 \\
.33\end{array}$ \\
\hline $\begin{array}{l}\text { BW, WW } \\
\text { BW, PW } \\
\text { WW, PW }\end{array}$ & & $\begin{array}{r}.23 \\
.06 \\
-.15\end{array}$ & $\begin{array}{r}.22 \\
.08 \\
-.11\end{array}$ & $\begin{array}{r}.25 \\
.09 \\
-.02\end{array}$ & $\begin{array}{r}.19 \\
.08 \\
-.16\end{array}$ & $\begin{array}{r}.18 \\
.09 \\
-.13\end{array}$ & $\begin{array}{r}.21 \\
.11 \\
-.10\end{array}$ \\
\hline $\begin{array}{l}\text { BW, WW } \\
\text { BW, PW } \\
\text { WW, PW }\end{array}$ & & $\begin{array}{r}.32 \\
.13 \\
-.06\end{array}$ & $\begin{array}{r}.32 \\
.13 \\
-.01 \\
\end{array}$ & $\begin{array}{l}.31 \\
.15 \\
.06\end{array}$ & $\begin{array}{l}\text { c correlations } \\
.35 \\
.15 \\
.00\end{array}$ & $\begin{array}{l}.33 \\
.15 \\
.02\end{array}$ & $\begin{array}{l}.31 \\
.16 \\
.06\end{array}$ \\
\hline
\end{tabular}

${ }^{\mathrm{a}} \mathrm{MGS}=$ maternal grandsire.

indicating likely response to selection on individual performance. However, a breeding objective for beef cattle weight traits is more likely to involve changing the shape of the growth curve rather than increasing weights at all ages. The moderate positive correlations between weights at different ages implies the existence of sires that, relative to breed average, will enable birth weights to be maintained or reduced while subsequent 
TABLE 14. DIRECT (D) AND MATERNAL (M) HERITABILITIES FROM LOG-TRANSFORMED BIRTH WEIGHT (BW), WEANING WEIGHT (WW) AND POSTWEANING GAIN (PW) BY SEX AND PERCENT SIMMENTAL

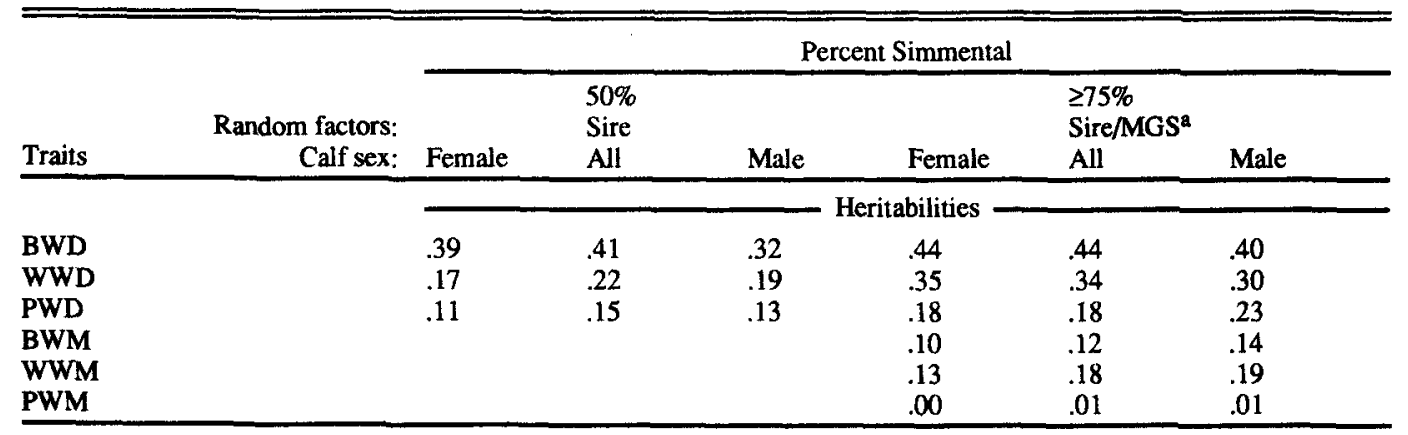

${ }^{\text {aMGS }}=$ maternal grandsire.

growth rates is increased. Accurate identification of these exceptional sires requires progeny testing.

This study had quantified heterogeneous phenotypic variance by sex-percent Simmental subclass and demonstrated that increased phenotypic variance arose from increased direct genetic, maternal genetic and residual partitions. Furthermore, the increase in direct genetic variance in males relative to females is not in proportion to the increase in residual variance, such that heritability is lower in males than in females. First-cross progeny exhibit less variation and lower heritability than later generations of Simmental cattle. No evidence has been found to suggest that the genetic correlation between different sexpercent subclasses is significantly different from unity.
Power transformers of the weight traits (including log-transformations) have the effect of reducing, but not removing, heterogeneous variance in birth and weaning weight. There remains a tendency for males to exhibit more variation than females for log-transformed birth and weaning weight. Transformations of postweaning gain did not reduce heterogeneity and resulted in male records exhibiting less variation than female records. It is unlikely that a transformation could be found that concurrently will stabilize direct genetic, maternal genetic and residual components of variance.

Models that have a single random factor can be easily modified to account for heterogeneous genetic and residual variances by scaling the observations to standardize the genetic variance, then using heterogeneous residual

TABLE 15. PERCENT OF HEIFER RECORDS BY PROGENY NUMBERS FOR 50\% AND $\geq 75 \%$ SIMMENTAL BULLS

\begin{tabular}{|c|c|c|c|c|c|c|c|c|}
\hline \multirow{3}{*}{$\begin{array}{l}\text { No. of } \\
\text { progeny }\end{array}$} & \multirow{3}{*}{$\begin{array}{l}\text { No. of } \\
\text { sires }\end{array}$} & \multicolumn{7}{|c|}{ Percent Simmental } \\
\hline & & \multicolumn{3}{|c|}{$\begin{array}{c}50 \% \\
\text { Percent heifer calves }\end{array}$} & \multirow{2}{*}{$\begin{array}{l}\text { No. of } \\
\text { sires }\end{array}$} & \multicolumn{3}{|c|}{$\begin{array}{c}\geq 75 \% \\
\text { Percent heifer calves }\end{array}$} \\
\hline & & Minimum & Mean & Maximum & & Minimum & Mean & Maximum \\
\hline 90.99 & 24 & 44 & 69 & 92 & 85 & 40 & 64 & 100 \\
\hline $100-199$ & 107 & 41 & 67 & 97 & 327 & 39 & 63 & 100 \\
\hline $200-299$ & 34 & 49 & 74 & 95 & 100 & 43 & 63 & 100 \\
\hline $300-399$ & 23 & 46 & 72 & 90 & 45 & 48 & 64 & 84 \\
\hline $400-499$ & 12 & 57 & 75 & 88 & 26 & 48 & 65 & 94 \\
\hline $500-599$ & 13 & 61 & 73 & 89 & 13 & 46 & 66 & 79 \\
\hline $600-699$ & 14 & 60 & 78 & 94 & 15 & 50 & 63 & 82 \\
\hline $700-799$ & 2 & 72 & 80 & 88 & 10 & 54 & 64 & 71 \\
\hline $800-899$ & 9 & 57 & 78 & 88 & 10 & 58 & 68 & 79 \\
\hline $900-999$ & 3 & 79 & 81 & 83 & 11 & 52 & 65 & 79 \\
\hline$\geq 1000$ & 42 & 71 & 83 & 95 & 68 & 55 & 66 & 80 \\
\hline
\end{tabular}


parameters. This is not possible for models with two or more random factors, unless the random factors can all be scaled by the same constant. In general, evaluations to account for heterogeneous genetic and residual effects require transforming the model (incidence) matrices for random effects, in addition to accounting for heterogeneous residual parameters (Garrick, 1988; Quaas et al., 1989).

If heterogeneous variance can be ignored in evaluations, in the absence of selection, the prediction error variance will be increased but the predictors will remain unbiased. However, the regression of predicted merit on actual merit generally will not be unity, resulting in under- or over-evaluations of individual animals, depending on subclass. Evaluations of sires will be misleading when progeny are unevenly distributed by subclass. The proportions of heifer records for Simmental bulls are given in Table 15, categorized by sire usage. Sires with wide use have variable reporting of progeny records by sex of calf. Evaluation using homogeneous parameters would underestimate superior bulls' evaluations based on predominantly female records, or predominantly $50 \%$ Simmental records.

Beginning in July 1988, national genetic evaluations of American Simmental cattle (using the sire-maternal grandsire model for birth weight direct and maternal effects, weaning weight direct and maternal effects and postweaning gain direct effects) account for heterogeneous genetic residual variances by sex-percent Simmental subclass.

Further research to investigate the adequacy of currently applied models, particularly with respect to the suitability of variance components, is recommended. Heterogeneous variance by age-of-dam and by herd are possible areas of interest for fine-tuning genetic evaluation systems.

\section{Literature Cited}

BIF. 1986. Guidelines for Uniform Beef Improvement Programs (5th Ed.). p 3-2. Beef Improvement Federation.

Dempster, A. P., N. M. Laird and D. B. Rubin. 1977. Maximum likelihood from incomplete data via the EM algorithm. J. Roy. Statist. Soc., Series B 39:1.

Dennis, J. E. and R. B. Schnabel. 1983. Numerical Methods for Unconstrained Optimization and Nonlinear Equations. Prentice-Hall, Inc., Englewood Cliffs, New Jersey.

Elzo, M. A., R. L. Quaas and E. J. Pollak. 1987. Effects of age of dam on weight traits in the Simmental population. J. Anim. Sci. 64:992.

Garrick, D. J. 1988. Restricted maximum likelihood estimation of variance components for multiple traits with missing observations and an application to beef cattle. Ph.D. Dissertation. Cornell Univ., Ithaca, New York.

Henderson, C. R. 1975. Comparison of alternative sire evaluation methods. J. Anim. Sci. 41:760.

Quaas, R. L. 1989. Transformed mixed model equations. A recursive algorithm to eliminate $\mathrm{A}^{-1}$. J. Dairy Sci. 72: 1937.

Quaas, R. L., D. J. Garrick and W. H. McElhenney. 1989. Multiple trait prediction for a type of model with heterogenous genetic and residual covariance structures. J. Anim. Sci. 67:2529. 